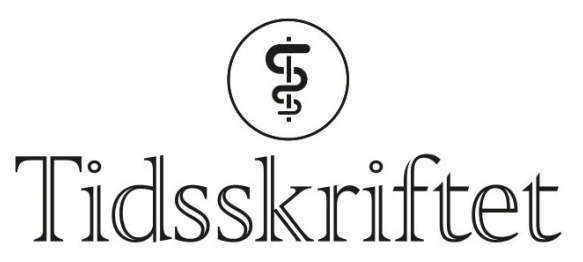

DEN NORSKE LEGEFORENING

\title{
Fluorokinolonbruk i sykehjem
}

\author{
AKTUELT \\ MARK FAGAN \\ Email:marfaga@online.no \\ Institutt for allmenn- og samfunnsmedisin \\ Universitetet i Oslo \\ Postboks 1130 Blindern \\ o318 Oslo \\ og \\ Tromøy Legesenter
}

STIAN BØE SKOTHEIM

Sørlandet Sykehus Arendal

\section{BAKGRUNN.}

Bruken av fluorokinoloner har økt betydelig i Norge de siste årene. Samtidig er det en bekymringsfull utvikling av ciprofloksacinresistens blant den vanligste urinveispatogene bakterien Escherichia coli. Eldre (over 70 år) er den aldersgruppen som bruker mest antibiotika. Hensikten med studien er å kartlegge fluorokinolonforskrivning til sykehjemsbeboere i Arendal kommune.

\section{MATERIALE OG METODE.}

Klinisk informasjon om sykehjemspasienter som ble behandlet med fluorokinoloner i løpet av perioden 1.12. 2006-31.11. 2007, ble registrert.

\section{RESULTATER.}

94 ciprofloksacinkurer ble forskrevet til 78 pasienter. Ingen pasienter fikk ofloksacin. Urinveisinfeksjon var den hyppigste indikasjon for pasienter på både langtids- (78 \%) og korttidsavdelinger (40\%). Luftveisinfeksjon var en nesten like hyppig indikasjon på kortidsavdelinger (37\%), men var det sjelden på langtidsavdelingene (4\%). 44 infeksjoner (47\%) ble verifisert med mikrobiologisk undersøkelse. 12 infeksjoner var forårsaket av en mikrobe som kun var følsom for ciprofloksacin.

\section{FORTOLKNING}

Hos en stor del av pasientene ble ciprofloksacin brukt der et annet antibiotikum, ifølge nasjonale retningslinjer for antibiotikabruk, er førstevalg. Flertallet av pasientene med en mikrobiologisk verifisert diagnose kunne ha brukt et antibiotikum med smalere spekter. 
$\emptyset \mathrm{kt}$ bruk av antibiotika har forårsaket resistensutvikling for flere typer bakterier (1). I andre land har man sett en bekymringsfull økning i fluorokinolonresistens (므). I disse landene har bruk av fluorokinolonene ciprofloksacin og ofloksacin vært høy sammenliknet med $\mathrm{i}$ Norge (3). Tidligere har fluorokinolonresistens blant de mest vanlige urinveispatogener vært lav i Norge. Nedsatt følsomhet for ciprofloksacin hos Escherichia coli har økt bekymringsfullt i løpet av de siste fem årene (4.). Salg av fluorokinoloner i Norge er mer enn fordoblet siden 1998 (Irene Litleskare, Avdeling for legemiddelepidemiologi, Divisjon for epidemiologi, Nasjonalt folkehelseinstitutt, personlig meddelelse)(5).

Det ble gitt markedsføringstillatelse for ciprofloksacin i Norge i 199o. Ciprofloksacin er et bredspektret antibiotikum med god effekt mot gramnegative bakterier og er et av de få bredspektrede antibiotika som kan brukes både peroralt og intravenøst. Det er mindre virksomt mot grampositive organismer, noe som gjør det uegnet for empirisk behandling av luftveisinfeksjoner. Indikasjonsområdene har inntil nylig vært begrenset til kompliserte urinveisinfeksjoner, resistente gonokokker, osteomyelitter samt alvorlige salmonellainfeksjoner ( $\underline{6}$ ). Ifølge norske retningslinjer for antibiotikabruk er fluorokinoloner ikke indisert som empirisk behandling av cystitt eller pneumoni, og kun unntaksvis for sepsis eller eksaserbasjoner av kronisk obstruktiv lungesykdom (kols) (7.)(9.).

I tillegg til resistensutvikling hos E. coli har fluorokinolonbruk vært assosiert med økt forekomst av meticillinresistente gule stafylokokker (MRSA) og utvidet spektrum

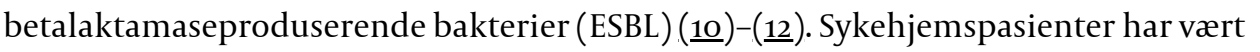
identifisert som en potensiell kilde til ESBL-mikrober (13). Bruk av flourokinoner er også forbundet med $\emptyset \mathrm{kt}$ antall alvorlige tilfeller av infeksjoner forårsaket av Clostridium difficile (14). Sykehjemspasienter er en utsatt risikogruppe for disse infeksjoner (15).

Eldre over 70 år er den aldersgruppen som bruker mest antibiotika i Norge og er den

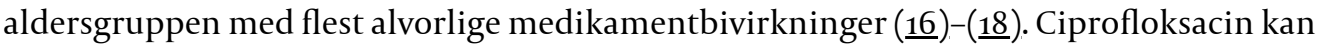
være kontraindisert hos eldre av flere grunner. Det skal helst ikke brukes hos pasienter med cerebral arteriosklerose, og det kan forårske forvirring og forverring av psykiske lidelser. Ciprofloksacin øker warfarinkonsentrasjonen, noe som gjør midlet uegnet hos eldre behandlet med warfarin.

Norske studier om antibiotikabruk i sykehjem er fra 1998 da fluorokinolonforskrivningen var på mindre enn halvparten av dagens nivå $(19, \underline{20})$. Blix og medarbeidere har vist store forskjeller i antibiotikaforskrivning mellom sykehjem uten en åpenbar medisinsk

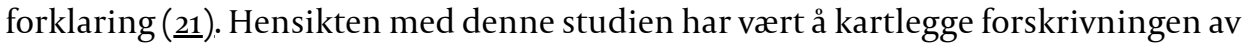
fluorokinolon til sykehjemsbeboere for å identifisere potensielle områder for forbedring av antibiotikaforskrivning.

\section{Materiale og metode}

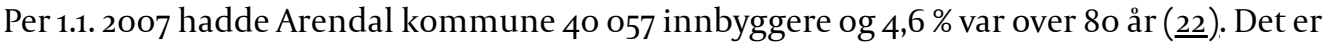
ti sykehjem i kommunen, med totalt 360 sengeplasser. Sykehjemsplassene var fordelt på 315 langtidsplasser og 45 korttidsplasser (ni rehabiliteringsplasser, 36 avlastingsplasser). Av de totalt 360 sengeplassene, var det til sammen 241 sengeplasser der legene benyttet det elektroniske journalsystemet GERICA ved forskrivning av medikamenter. Legetjenesten ved sykehjemmene ble utført av 17 forskjellige leger.

Vi registrerte forskrivning av fluorokinoloner til pasienter innlagt på sykehjem der man brukte GERICA i ettårsperioden 1.12. 2006 til 30.11. 2007. Ved å bruke anatomisk terapeutisk kjemisk legemiddelregister (ATC) i GERICA fikk vi en liste over alle pasienter som hadde fått forskrevet ciprofloksacin (Jo1MAo2) eller ofloksacin (Jo1MAo1) i den aktuelle tidsperioden. Hos disse pasientene ble lege- og sykepleienotater gjennomgått. Følgende ble registrert: pasientens kjønn, alder, avdeling (korttids eller langtids), antibiotikaindikasjon 
med dosering og behandlingslengde, og forskrivende lege (sykehjemslege, sykehuslege, eller legevaktlege). Epikriser ble innhentet for pasienter overført fra sykehus for å finne indikasjon for forskriving av ciprofloksacin/ofloksacin.

Mikrobiologisk avdeling ved Sørlandet sykehus ble kontaktet for opplysninger om dyrkingssvar og resistensbestemmelse i de tilfellene bakteriologisk diagnostikk ble utført. Studien er vurdert av regional etisk komité som en kvalitetssikringsstudie, og konsesjon er vurdert av Datatilsynet og ikke funnet nødvendig.

\section{Resultater}

I perioden fikk 78 pasienter forskrevet ciprofloksacin, hvorav 62 var kvinner og 16 menn. Gjennomsnittsalderen på behandlede pasienter var på langtidsavdelingene 84,3 år og på korttidsavdelingene 83,6 år.

Til de 78 pasientene, ble det forskrevet 94 ciprofloksacinkurer, hvorav 51 kurer var til 43 pasienter innlagt på langtidsavdelinger og 43 kurer til 35 pasienter innlagt på korttidsavdelinger. De fleste som fikk ciprofloksacin, fikk kun en enkelt kur i observasjonsperioden. 11 pasienter fikk mer enn en kur; sju fikk to kurer og fire fikk tre kurer. Ingen pasienter fikk forskrevet ofloksacin.

Gjennomsnittlig daglig dosering var $882 \mathrm{mg}$ for pasienter ved langtidsavdelingene og 877 mg ved korttidsavdelingene. Median dosering for begge avdelinger var 1 ooo mg per $\mathrm{d} \emptyset \mathrm{g}$.

På langtidsavdelingene ble ciprofloksacin som oftest ordinert av en sykehjemslege, mens det på korttidsavdelingene som oftest ble ordinært av en sykehuslege (fig 1).

\section{Antall kurer med ciprofloksacin}

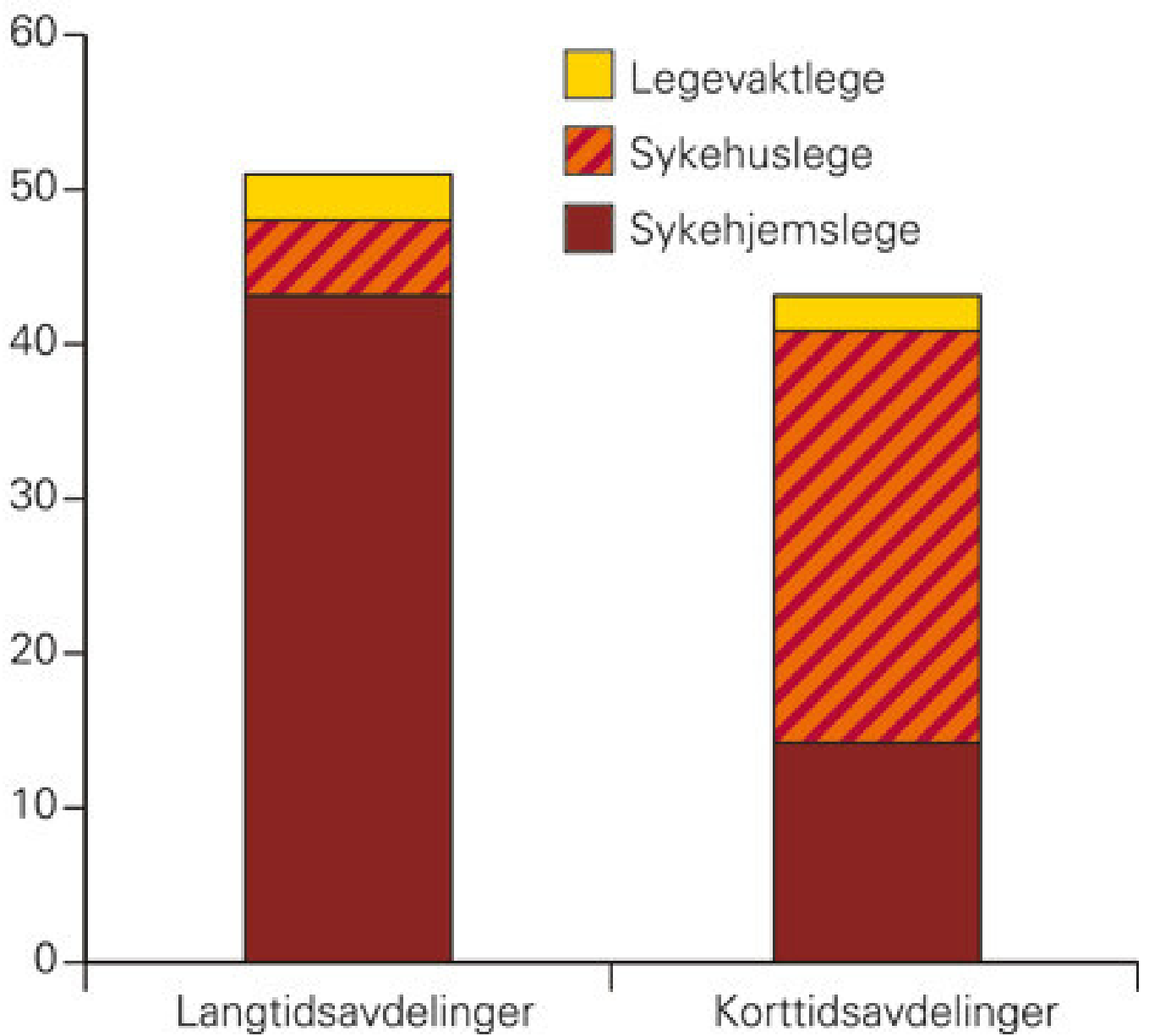

Figur 1 Forskrivende lege på langtidsavdeling og på korttidsavdeling, antall kurer med ciprofloksacin

INDIKASJON (FIG 2) 
På langtidsavdelinger var urinveisinfeksjon indikasjon i 78 \% av tilfellene, luftveisinfeksjon sammen med urinveisinfeksjon i $6 \%$, luftveisinfeksjon alene i $4 \%$ og uspesifisert infeksjon i $6 \%$. De resterende $6 \%$ bestå av to pasienter med hudinfeksjon, én pasient med peritonitt, én med divertikulitt og én med bakteriell vaginose. På korttidsavdelinger var urinveisinfeksjon indikasjon i $40 \%$ av tilfellene, luftveisinfeksjon sammen med urinveisinfeksjon i 7 \%, luftveisinfeksjon alene i 37 \%, uspesifisert infeksjon i $9 \%$ og hudinfeksjon i $5 \%$. Én pasient ble behandlet på mistanke om salmonellaenteritt.

\section{Antall kurer}

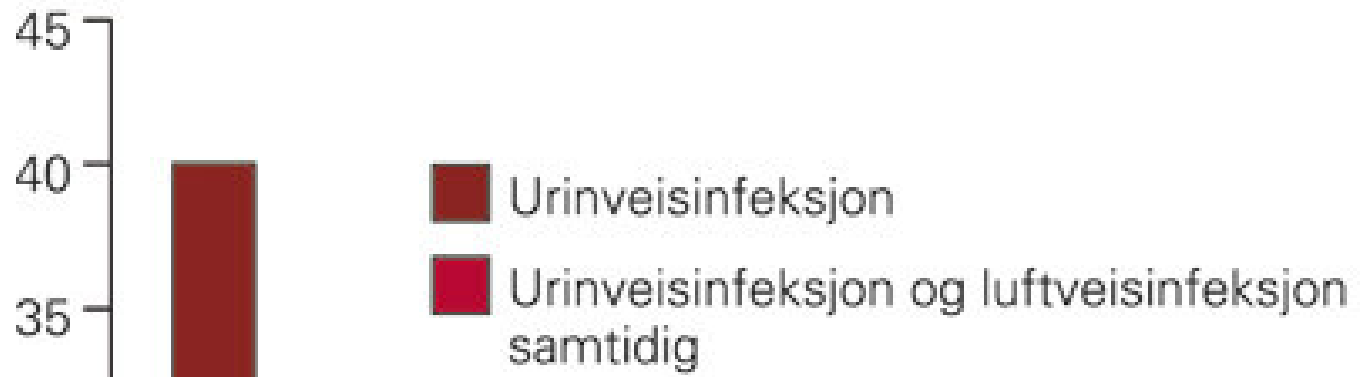

Zuftveisinfeksjon

$\square$ Uspesifisert infeksjon
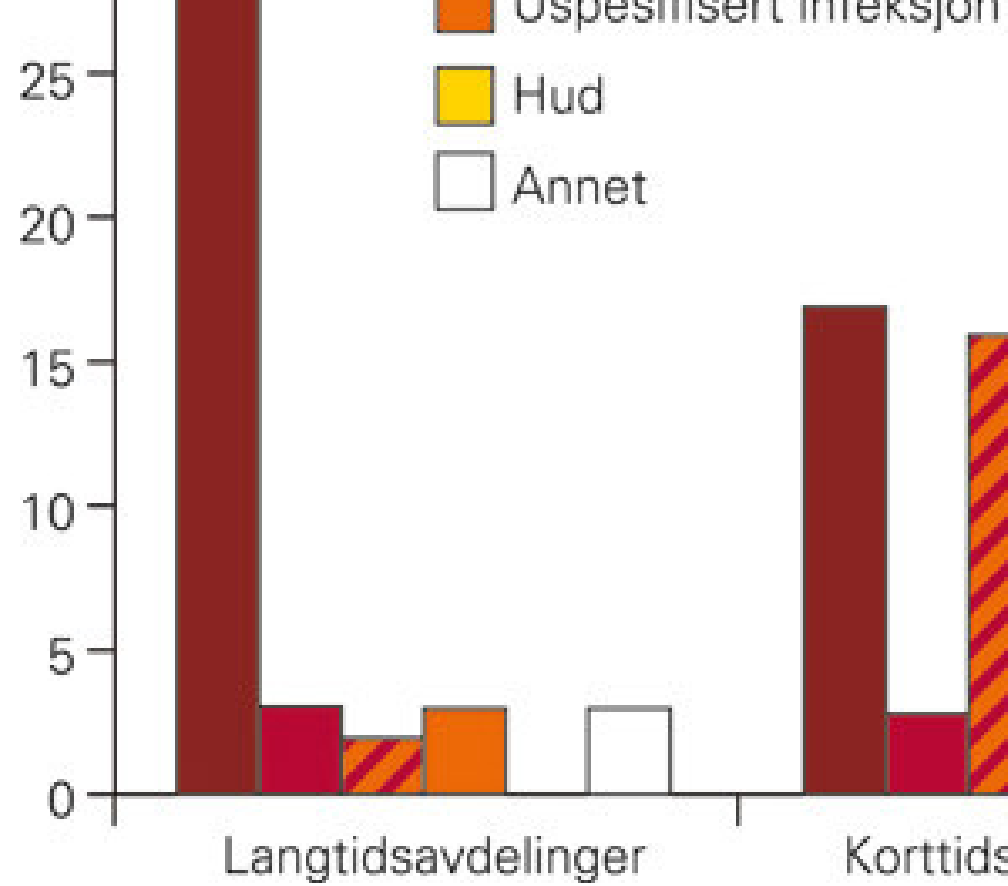

Korttidsavdelinger

Figur 2 Indikasjon for forskrivning av ciprofloksacin ved langtids- og korttidsavdelinger, antall kurer

DIAGNOSTIKK

Ved $50(53 \%)$ av de infeksjonene som ble behandlet med ciprofloksacin, ble det utført mikrobiologisk diagnostikk. Åtte (9\%) dyrkingsprøver viste ingen oppvekst og seks (6\%) var forurenset. 36 (38\%) infeksjoner var diagnostisert med et positivt dyrkingssvar. Av disse var 12 (13\%) forårsaket av en mikrobe som kun var følsom for ciprofloksacin: seks Proteus, fire Pseudomonas og to E. coli. To av pseudomonasinfeksjonene var hos én pasient.

\section{Diskusjon}

De fleste forskrivninger av fluorokinoloner var utført av en sykehjemslege på langtidsavdelinger, og av en sykehuslege på korttidsavdelinger. Det var en klar forskjell i indikasjon for ciprofloksacinforskrivning mellom langtids- og korttidsavdelinger. På langtidsavdelingene var de fleste kurer hovedsakelig forskrevet for urinveisinfeksjoner. 
På korttidsavdelingene var urinveisinfeksjoner mindre dominerende som indikasjon, og en større andel pasienter ble behandlet for en luftveisinfeksjon eller en tilstand hvor det var vanskelig å vite om pasienten hadde en luftveisinfeksjon, en urinveisinfeksjon eller begge infeksjoner samtidig. Dette er tankevekkende. Ciprofloksacin har dårlig grampositiv dekning som gjør midlet uegnet til empirisk behandling av luftveisinfeksjoner.

Nasjonale retningslinjer for antibiotikabruk anbefaler ikke fluorokinoloner som førstevalgsbehandling av verken pneumoni, kols i forverring, urinveisinfeksjon eller sepsis $(\underline{6}, 7,7.9$.$) . Selv når legene er kjent med retningslinjene, er det ingen garanti at de følge disse$ (22). Andre tiltak er nødvendig for å bedre antibiotikaforskrivning. Gjennomgang (audit) med tilbakemelding til legene om deres forskrivningspraksis kan bidra til bedret antibiotikaforskrivning (23). Reduksjon i fluorokinolonbruk kan også skje ved å innføre restriksjoner på forskrivning av fluorokinoloner til infeksjoner med en verifisert mikrobiologisk agens (24).

De fleste pasienter som fikk ciprofloksacin, uansett avdeling, hadde en urinveisinfeksjon. Fluorokinoloner er kun indisert for kompliserte urinveisinfeksjoner, men ikke som førstevalg (므)-(9). Fluorokinoloner har ingen plass i behandling av ukomplisert cystitt med mindre det er terapisvikt og det foreligger et positivt dyrkingssvar på en mikrobe som kun er følsom for et fluorokinolon.

Statens legemiddelverk anbefaler restriktiv bruk, men har likevel godkjent utvidet indikasjonsområde for fluorokinoloner fra desember 2008 (25). Begrunnelsen er at norske indikasjoner må harmoniseres med indikasjoner i EU. Dette til tross for store forskjeller i resistensproblematikk mellom europeiske land (므). En liberalisering av indikasjonsområdet vil sannsynligvis $\emptyset \mathrm{ke}$ forskrivningen. Da risikerer Norge å få alvorlige resistensproblemer, som i land med et høyere forbruk av fluorokinoloner $(3,27$.$) .$

\section{DIAGNOSTIKK/MIKROBIOLOGI}

Flertallet av pasientene i denne studien ble behandlet med fluorokinoloner uten noen forutgående mikrobiologisk diagnostikk. Blodkultur er aktuelt i diagnostikk av inneliggende pasienter med pneumoni eller sepsis. Dyrking av urin og blod er aktuelt ved mistanke om kompliserte urinveisinfeksjoner. Der man initialt starter med bredspektret behandling, bør det byttes til smalspektret så snart dyrkingssvar med resistensbestemmelse foreligger. Slik praksis kan redusere unødvendig bruk av

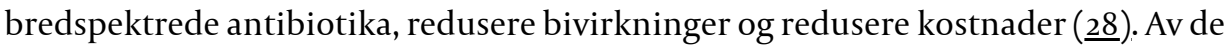
pasientene som var blitt vurdert med mikrobiologisk diagnostikk, kunne de fleste av dem som fikk ciprofloksacin initialt, vært behandlet med et mindre bredspektret antibiotikum.

Mangel på mikrobiologisk diagnostikk gjaldt spesielt pasienter som fikk mer enn én kur. Her ble kun $42 \%$ testet. Dette er tankevekkende fordi pasienter behandlet med gjentatte antibiotikakurer er mer utsatt for infeksjoner med resistente mikrober. Det er et spørsmål om empirisk behandling med ciprofloksacin hos de $58 \%$ som ikke ble testet, var berettiget.

En svakhet med denne retrospektive studien, er at datainnsamlingen er begrenset av det som ble dokumentert i journalen. Av den grunn var det ikke mulig å vite årsaken til forskrivning i $7 \%$ av forskrivningene. Av den samme grunn var det ikke mulig å skille mellom øvre og nedre urinveisinfeksjoner og heller ikke mulig å si noe sikkert om bruk av annen diagnostikk som urinstiks og C-reaktivt protein (CRP).

Ofloksacin er det andre registrerte fluorokinolon i Norge. Det har en virkningsmekanisme og en mikrobiologisk effekt svært likt ciprofloksacin. Det metaboliseres renalt, noe som kompliserer bruken hos eldre med nedsatt nyrefunksjon. Om dette er årsaken til at kun ciprofloksacin ble forskrevet, kan ikke studien besvare.

\section{Konklusjon}


En stor andel av pasientene som fikk ciprofloksacin, ble behandlet for infeksjoner der et annet antibiotikum ifølge nasjonale retningslinjer skulle vært førstevalg. Få pasienter hadde en mikrobiologisk verifisert diagnose. Flertallet av pasientene med en mikrobiologisk diagnose kunne ha brukt et antibiotikum med smalere spekter. Tiltak for å redusere unødvendig fluorokinolonbruk må rettes mot både sykehjemsleger og sykehusleger.

Vi takker Mikrobiologisk laboratorium Sørlandet Sykehus Kristiansand, Christian Borchgrevink og den allmennmedisinske Forskergruppen i Aust-Agder for støtte og veiledning. Vi takker Froland folkebibliotek for litteraturhjelp. Studien er støttet av Allmennpraktikerstipend, Antibiotikasenteret for Primcerhelsetjenesten (ASP) og Norsk overvåkningssystem for antibiotikaresistens hos mikrober (NORM).

\section{Oppgitte interessekonflikter:}

Ingen

\section{Tabell}

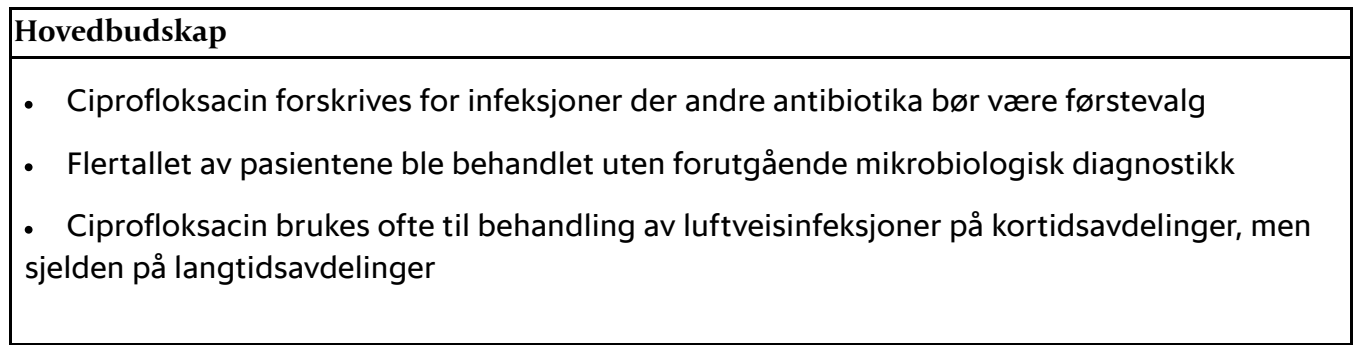

\section{LITTERATUR}

1. World Health Organization Report on Infectious Diseases 20oo. Overcoming antimicrobial resistance. Genève: WHO, 200o. www.who.int/infectious-disease-report/200o/index.html (6.4.2009).

2. The European Antimicrobial Resistance Surveillance System. www.rivm.nl/earss/ (6.4.2009).

3. Goossens H, Ferech M, Vander Stichele R et al. Outpatient antibiotic use in Europe and association with resistance: a cross-national database study. Lancet 2005;365: 579-87.

4. NORM/NORM-VET 2007. Usage of antimicrobial agents and occurrence of antimicrobial resistance in Norway. Tromsø/Oslo: Veterinærinstituttet, 2008.

5. Legemiddelforbruket i Norge. www.legemiddelforbruk.no (6.4.2009).

6. Smittevernloven - håndbok. Bruk av antibiotika i sykehus. Oslo: Statens helsetilsyn, 2001. www.helsedirektoratet.no/vp/multimedia/archive/oooo3/ik-2737_3321a.pdf(6.4.2009).

7. Kompetansesenter for rasjonell antibiotikabruk i Helse Øst.

www.aus.no/modules/module_123/proxy.asp? $\mathrm{D}=2 \& \mathrm{C}=555 \& \mathrm{I}=5682 \&$ mids=844a1017 (6.4.2009).

8. Veiledning i bruk av antibiotika for Helse Vest. http://antibiotika.ihelse.net (6.4.2009).

9. Lindbæk M, red. Nasjonale faglige retningslinjer for antibiotikabruk i primærhelsetjenesten. Oslo: Helsedirektoratet, 2008. www.helsebiblioteket.no/microsite/antibiotikaretningslinjer (6.4.2009).

10. Wiener J, Quinn JP, Bradford PA et al. Multiple antibiotic-resistant Klebsiella and Escherichia coli in nursing homes. JAMA 1999; 281: 517-23. [PubMed] [CrossRef] 
11. Colodner R, Rock W, Chazan B et al. Risk factors for the development of extended-spectrum betalactamase-producing bacteria in nonhospitalized patients. Eur J Clin Microbiol Infect Dis 2004; 23: 163-7. [PubMed] [CrossRef]

12. Blumberg HM, Rimland D, Carroll DJ et al. Rapid development of ciprofloxacin resistance in methicillin-susceptible and -resistant Staphylococcus aureus. J Infect Dis 1991; 163: 1279-85. [PubMed]

13. Wiener J, Quinn JP, Bradford PA et al. Multiple antibiotic-resistant Klebsiella and Escherichia coli in nursing homes. JAMA 1999; 281: 517-23. [PubMed] [CrossRef]

14. Kuijper EJ, Coignard B, Tüll P et al. Emergence of Clostridium difficile-associated disease in North America and Europe. Clin Microbiol Infect 2006; 12 (suppl 6): 2-18. [PubMed] [CrossRef]

15. Denève $C$, Janoir $C$, Poilane I et al. New trends in Clostridium difficile virulence and pathogenesis. Int J Antimicrob Agents 2009; 33 (suppl 1): S24-8. [PubMed] [CrossRef]

16. Litleskare I, Blix HS, Rønning M. Antibiotikaforbruk i Norge. Tidsskr Nor Legeforen 2008; 128: 2324-9.

17. Alexopoulou A, Dourakis SP, Mantzoukis D et al. Adverse drug reactions as a cause of hospital admissions: a 6-month experience in a single center in Greece. Eur J Intern Med 2008; 19:505-10. [PubMed] [CrossRef]

18. Ebbesen J, Buajordet I, Erikssen J et al. Drug-related deaths in a department of internal medicine. Arch Intern Med 2001; 161: 2317-23. [PubMed] [CrossRef]

19. Bucher A, Sorknes N, Lundquist K. Infeksjoner og antibiotikabehandling ved sykehjem. Tidsskr Nor Lægeforen 2001; 7: 827-30.

20. Tobiassen T, Berild D, Hjortdahl P. Bruk av systemiske antibiotika ved et norsk sykehjem. Tidsskr Nor Lægeforen 2002; 24: 2376-8.

21. Blix HS, Røed J, Sti MO. Large variation in antibacterial use among Norwegian nursing homes. Scand J Infect Dis 2007; 39: 536-41. [PubMed] [CrossRef]

22. Lomas J, Anderson GM, Domnick-Pierre K et al. Do practice guidelines guide practice? The effect of a consensus statement on the practice of physicians. N Engl J Med 1989;321: 1306-11. [PubMed] [CrossRef]

23. Munck AP, Gahrn-Hansen B, Søgaard P et al. Long-lasting improvement in general practitioners' prescribing of antibiotics by means of medical audit. Scand J Prim Health Care 1999; 17: 185-90. [PubMed] [CrossRef]

24. Cizman M, Srovin T, Pokorn M et al. Analysis of the causes and consequences of decreased antibiotic consumption over the last 5 years in Slovenia. J Antimicrob Chemother 2005; 55: 758-63. [PubMed] [CrossRef]

25. Statistisk sentralbyrå. http://statbank.ssb.no/statistikkbanken/(6.4.2009).

26. Statens legemiddelverk. www.legemiddelverket.no/templates/InterPage (6.4.2009). 8o668.aspx

27. European Antimicrobial Resistance Surveillance System. www.rivm.nl/earss/database/ (6.4.2009).

28. Berild D, Mohseni A, Diep LM et al. Adjustment of antibiotic treatment according to the results of blood cultures leads to decreased antibiotic use and costs. J Antimicrob Chemother 2006; 57:326-30. [PubMed] [CrossRef]

Publisert: 21. oktober 2010. Tidsskr Nor Legeforen. DOI: 10.4045/tidsskr.09.056o Manuskriptet ble mottatt 23.4. 2009 og godkjent 29.4. 2010. Medisinsk redaktør Åslaug Helland. (C) Tidsskrift for Den norske legeforening 2023. Lastet ned fra tidsskriftet.no 26. april 2023. 